\title{
Evaluating farm and export competitiveness of the Irish dairy industry: post-quota analysis
}

Lungelo Prince Cele

Department of Food Business and Development, College of Business and Law, University College Cork, Cork, Ireland

Thia Hennessy

College of Business and Law, University College Cork, Cork, Ireland, and

Fiona Thorne

Department of Rural Economy and Development Centre, Teagasc Food Research Centre Ashtown, Dublin, Ireland

\begin{abstract}
Purpose - This paper aims to examine the competitiveness trends and rankings of the Irish dairy sector at the farm and trade levels, relative to selected European Union (EU) Member States, in the context of the removal of the EU milk quota in 2015.

Design/methodology/approach - Competitiveness indicators including partial productivity measures and accountancy-based indicators were used for farm competitiveness, and net export market share and normalised revealed comparative advantage (NRCA) were used for export competitiveness.

Findings - Amongst the countries examined, Ireland had the highest growth in partial productivity indicators and was ranked first with the lowest total costs and cash costs per kg of milk solids post-quota. However, the total economic cost sub-components showed that Irish dairy farmers had high opportunity costs for owned land and labour. While Irish dairy products such as butter and powders have demonstrated growth potential in competitiveness post-quota with Irish butter and whey ranked in top three relative to other countries, other products, i.e. cheese and liquid milk have declined in competitiveness according to key export competitiveness indicators used.
\end{abstract}

Practical implications - The challenge for Irish dairy farmers is how to mitigate relatively high land and labour costs, which can limit farm competitiveness in the long run. The key players in the Irish dairy industry can now better position themselves in the global dairy market, recognizing the competitiveness dynamics of the different dairy products and their competitors. Policy implications and further areas of research have been identified to help improve the overall competitiveness position. It is surprising that Irish butter is a leader in the EU, yet not much research has been done to understand the market dynamics of this sector.

Originality/value - To the best of the authors' knowledge, this study is the first of its kind to use both farm and export competitiveness measures to analyse the Irish dairy industry relative to other countries in the context of quota abolition. Unlike previous studies on dairy export competitiveness, this study has

(C) Lungelo Prince Cele, Thia Hennessy and Fiona Thorne. Published by Emerald Publishing Limited. This article is published under the Creative Commons Attribution (CC BY 4.0) licence. Anyone may reproduce, distribute, translate and create derivative works of this article (for both commercial and non-commercial purposes), subject to full attribution to the original publication and authors. The full terms of this licence may be seen at http://creativecommons.org/licences/by/4.0/legalcode

This project is funded by Teagasc - the Irish Agriculture and Food Development Authority under the Walsh Scholarships Programme.
Irish dairy industry

Received 3 November 2020

Revised 2 February 2021 2 April 2021

Accepted 17 April 2021 
$\mathrm{CR}$ 32,7

2

disaggregated the processed dairy products, which allowed for the ranking of countries and comparability across countries using NRCA.

Keywords Accountancy-based indicators, Country/competitiveness rankings, EU Dairy industry, Normalised revealed competitive advantage, Partial productivity,

Farm and export competitiveness assessment

Paper type Research paper

\section{Introduction}

The dairy industry in the European Union (EU) has undergone significant structural adjustments over the years due to changes in factors such as prices, weather, environment and policies (Giles, 2015; Läpple and Sirr, 2019). Of particular importance to this study is the removal of the EU milk quota regime in 2015. The milk quota system was introduced in 1984 to contain the growth of milk production and to ensure that the EU would be able to continue to fund the growing cost of the price support framework (Donnellan et al., 2011; Groeneveld et al., 2016). This ensured that the EU dairy market would have little or no surplus in the EU public storage for products such as butter and skimmed milk powder. While the policy was beneficial in the beginning, it later became a constraint in the development of the industry because the demand for dairy exports was growing much faster than supply (Donnellan et al., 2011; Donnellan et al., 2015), especially for Ireland. The European Commission increased the milk quota by $2 \%$ in 2008 and gradually increased it by $1 \%$ per annum thereafter until 2013 to allow for a "soft-landing" scenario or a smooth transition to eventual removal in 2015.

The most efficient EU dairy producing countries depended on the easing of the quota restrictions to maintain and improve their competitiveness position in the world market. Viira et al. (2015) conducted research in the pre-quota abolition period and classified dairy farmers in countries such as Germany, Italy, The Netherlands and Ireland as competitive milk producers with a high impact on the EU dairy market. Likewise, Bojnec and Fert'” (2014) found that Belgium, Denmark, France, Ireland and The Netherlands had a competitive advantage in the global market. Based on that, Jansik et al. (2014) noted that Ireland, The Netherlands, Germany and Denmark were most constrained by the milk quota system. According to Giles (2015), countries that had high growth potential post-quota were those countries with a comparative advantage in the international market, e.g. Ireland, Denmark and The Netherlands. Therefore, the milk quota abolition prompted dairy farmers in those countries to evaluate their short-term positions regarding milk production and to decide whether to expand, remain static or exit millk production altogether to survive in the evolving market situation. According to Porter (1998), there is a need to periodically conduct a competitiveness assessment for industries, using the latest data and relevant indicators.

Previously, Donnellan et al. (2015) found that the average milk production growth rate in Ireland was about 10\% per year between 1970 and 1984, while in France, Germany, Denmark and the UK it averaged at about $2 \%$. Recently, Läpple and Sirr (2019) noted that a year after the quota removal, milk production in Ireland increased by $18.5 \%$, the fastest rate in the EU, compared to an average growth rate of $4.5 \%$ across the EU. Ireland opposed the introduction of the milk quota system and welcomed its abolition (Donnellan et al., 2015). Therefore, it remains an appealing area of study to review how the Irish dairy industry has performed following the policy change relative to other EU countries such as The Netherlands, Germany, France, Italy, Belgium, Denmark and the UK. According to Martin et al. (1991), government policies can influence the choice of strategy that the farms or firms pursue. Given this context, some questions remain, how has the Irish and EU dairy industry evolved at the farm- and trade-level? How was Ireland positioned (competitiveness ranking) pre (2012-2014) and post (2015-2017) quota relative to other EU countries? Where or in which dairy products did trade grow or diminish? 
Previous studies such as Viira et al. (2015) analysed the competitiveness of the Hungarian dairy industry from farm to trade, and Bojnec and Ferto (2014) analysed EU dairy export competitiveness. However, these studies were limited in the following ways. The data analysed in these studies ended in 2014, before the quota abolition. The main measure used, e.g. the revealed comparative advantage (RCA), prevented the comparison of countries at the trade-level (Yu et al., 2009). Dairy products were analysed as one homogenous group, even though they have significant differences. The probability of a country to lose its RCA position is high when it has a broad product portfolio, even though this may be maintained for risk management. This is based on competitiveness theory, which states that countries must direct their resources to products that share similar resources and that they are good at producing (Boyle, 2002; Suwannarat, 2017). This means that a country can have a comparative advantage for a group of processed dairy products but have a competitive disadvantage in products within the same group. This makes it difficult to compare across countries, as one country could have a comparative advantage in butter but not in cheese and vice versa.

This paper contributes to the existing literature by identifying industry trends, ranking and comparing countries based on their competitiveness in dairy farm production and international trade of different dairy products. The competitiveness assessment provides insights that can assist decision-makers in the Irish dairy industry to identify which dairy products to prioritise for production, improvement and promotion (Fetscherin et al., 2012). According to Martin et al. (1991), it is important to separate the web of causality between public policy, private management strategy and the food industry's competitiveness state. In the following sections, this paper will provide the contextual background of the Irish and EU dairy industry. It will then review relevant literature on previous studies of competitiveness in agriculture or the dairy industry which will help to guide the direction of this study. The methodology for farm- and trade-level measures will then be provided. This will be followed by the results section. The pen-ultimate section will provide a discussion of the results and the policy implications that arise from application of the competitiveness assessment. Finally, a conclusion will be made by restating the main arguments and highlighting areas for further research.

\section{Background of the Irish and selected European Union countries' dairy industry}

\subsection{Production of raw milk delivered to processors}

In 2017 , Germany $(21 \%)$, France $(16 \%)$, the UK $(10 \%)$, The Netherlands $(9 \%)$, Poland $(8 \%)$ and Italy $(7 \%)$ collectively provided over two-thirds $(70 \%)$ of the raw cows' milk produced on farms and collected by dairies in the EU (EU-28 total of 154.8 million tonnes- MT), Ireland contributed 5\% (Eurostat, 2019). While the Irish contribution was relatively low in terms of quantity produced. Figure 1 demonstrates that Ireland had the highest growth rate of $25 \%$

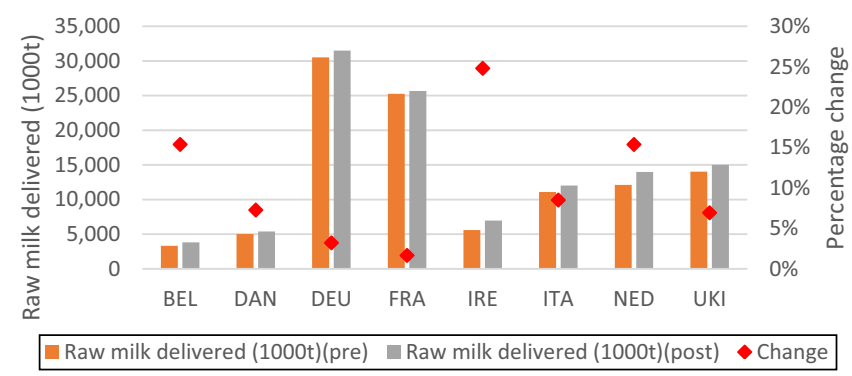

Source: Authors' calculations based on Eurostat database Irish dairy
industry

Figure 1.

Changes in raw milk delivered pre (20122014) and post (20152017) quota 
CR

32,7

4

Figure 2.

Total dairy products export and import quantity preand post-quota
Figure 3.

Total dairy products export and import price $(€)$ per kg pre and post-quota in raw milk deliveries post-quota, driven by exports, from 5.6 to 7 MT supplied to creameries and pasteurisers. The growth was significant for a relatively small country like Ireland. This is in line with the Food Wise 2025 policy for Ireland which advocated for growth in production and export expansion. The Food Wise 2025 strategy was published in 2015, which coincided with the milk quota abolition. It outlined expansion goals for the Irish agri-food sector with the dairy industry featuring prominently.

\subsection{Trends in dairy products' exports and imports}

In 2019, the exported edible Irish food and drinks industry contributed $€ 12.9 \mathrm{bn}$ to the economy, and the dairy industry had the highest contribution of 34\% (National Milk Agency, 2019), making it one of the most significant industries. Ireland is one of the most prominent exporters in the EU. For example, Ireland contributed $4 \%$ to the total EU export quantity in 2017 compared to $20 \%$ for Germany, 10\% for France and 3\% for Italy, of 20.6 MT. For total dairy products, Irish export quantity grew by $7 \%$ and had the highest rise in export price $/ \mathrm{kg}$ of $3 \%$, while import quantity growth was the highest at $45 \%$ with the highest decline in import price/kg of $24 \%$ post-quota. This is illustrated in Figures 2 and 3 for quantity and for price/kg, respectively. The rise in Irish export price/kg slowed the growth in export quantity. Italy had the largest reduction in export price/kg of $13 \%$ and the highest growth in export quantity of $39 \%$. This is due to the different profile of dairy products per country.

The Irish export quantity post-quota comprised of cheese, butter, skimmed dried milk, skimmed cow, whey, whole dried and whole milk at 30\%, 28\%,11\%,10\%, 10\%, $8 \%$ and

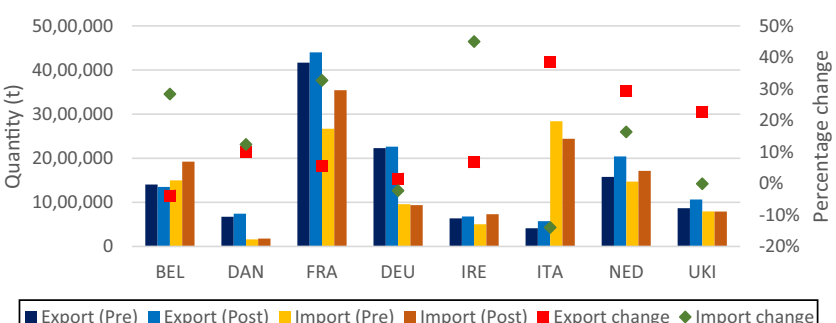

Source: Authors' calculations based on FAOstat database

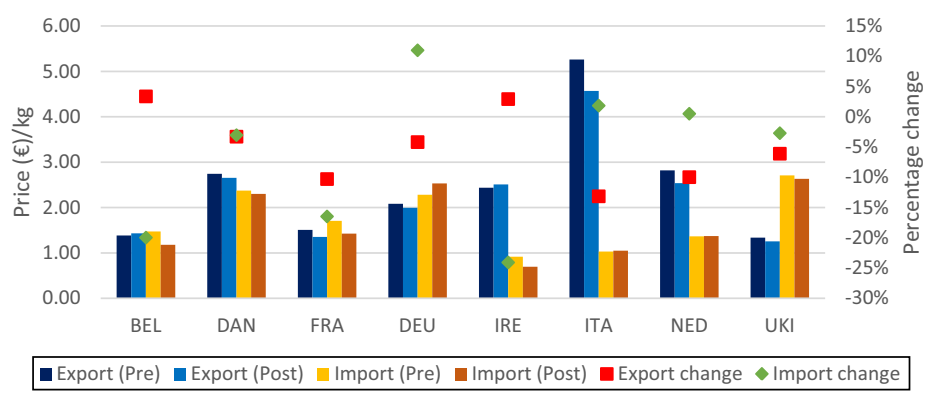

Source: Authors' calculations based on FAOstat database 
$4 \%$, respectively, of 680 thousand tonnes (TT). For Ireland, the highest export quantity growth came from skimmed dried milk, while the largest decline was in whole fresh milk. The growth in Irish imports was mostly due to the importation of raw milk which, grew by $56 \%$ to 587 TT (Figure A1 in the appendix) and constituted $80 \%$ of the total quantity imported post-quota. According to National Milk Agency (2019), from the 651 TT of imported milk, excluding imports of fresh milk in consumer packs, $92 \%$ was for processing into manufactured dairy products and $8 \%$ was for processing into liquid/fresh milk for consumption. In 2019, the Irish fresh milk market was worth about $€ 514 \mathrm{~m}$ in retail value (for 578 TT), the largest consumer market in domestic milk and milk products at 118 litres per capita per annum, the highest in the world (National Milk Agency, 2019).

\section{Literature review on competitiveness}

3.1 Definition of competitiveness from farm- to trade-level in the dairy industry

Policy changes in domestic and international markets continue to be the primary driver of competitiveness research (Jansik et al., 2014; Thorne et al., 2017). Research on the implications of the changes in price-distorting support systems is expected to grow, as more countries become engaged in and exposed to world markets where productivity and profitability are essential for the survival of an industry (Boyle, 2002; Bojnec and Ferto, 2014). The concept of competitiveness holds many definitions in the literature due to its complex and dynamic nature, which can vary by industry. Various authors have chosen definitions that match their areas of interest (Latruffe, 2010) and the kind of data they have available to compute their measures. According to Fetscherin et al. (2012), an industry-level analysis enables inter-country comparisons of a given industry, which provides greater detail and a better understanding of the export competitiveness dynamics of countries. At an industry-level, such as the dairy industry, competitiveness measures can be analysed at three sub-levels, namely, farm and firm (processing) production levels and trade-level in international markets, i.e. country's trade balance. However, the competitiveness assessment of the dairy industry in this study excludes firm-level competitiveness due to lack of data on public data sources.

Based on previous literature, the definition of competitiveness in the three sub-levels for dairy and related industries can be summed up as follows. At the farm- and firm-level, the definition tends to lean towards productivity and profitability often regarded as leading performance indicators under the strategic management theory which emphasises cost leadership and product differentiation (i.e. brand identification or image and customer loyalty) to increase productivity and profitability (Boyle, 2002; Thorne and Fingleton, 2006; Latruffe, 2010). At the trade-level, the definition leans towards industrial organisation theory or international trade theory for increasing profits and maintaining market share (Martin et al., 1991) and the concept of comparative advantage (country's relative costefficiency based on the inputs into the production process) (Porter, 1998; Fetscherin et al., 2012; Bojnec and Fertö, 2014). Previous references focus on market demand and supply for firm products and influencing factors. Therefore, competitiveness in this study is defined as the combined measure of farm and trade performance of dairy products over a period. A country can be considered competitive when it can increase its performance and reduce its production costs at the farm-level and grow or maintain its market share in the domestic and world market. Improving and promoting the quality of exports while protecting the domestic industry from unrestrained imports in the country, can also be considered as a measure of competitiveness.

Irish dairy industry

\section{西}


$\mathrm{CR}$

32,7

\subsection{Determinants of competitiveness in the dairy industry}

Competitiveness, at micro or farm-level, is affected by the farm/firm's operations and strategy, market structure, quantity and quality of production factors, price changes, economies of scale (unit costs reduction), the environment, animal welfare, scale of the enterprise, technology and innovations (Dillon et al., 2008). At macro or trade-level, competitiveness is influenced by monetary and fiscal policy, the rule of law and the quality of social and political institutions (Latruffe, 2010; Viira et al., 2015) which are essential for farmers and processing firms to make decisions on long-term investments. Porter (1998) identified other factors such as the intensity of rivalry among existing competitors, capital requirements, favourable access to raw materials, favourable locations, changes in the exchange rate and government policy or support. These factors can be captured qualitatively and quantitatively. The qualitative factors are normally not readily available as secondary data compared to the quantitative data. Therefore, this study will be limited to the factors that have secondary data which is publicly accessible.

According to Martin et al. (1991), the drivers provide particular concepts on which to focus in determining the state of competitiveness of an industry. The lack of secondary data available for some measures limits the possibility to test the relationship between the drivers and the state of competitiveness. However, the condition of the drivers across countries at different points in time can provide an indication of the state of competitiveness of the industry. Buckley et al. (1988) classifies competitiveness measures into three categories. Potential measures, which describe the inputs into the operation e.g. comparative advantage, cost competitiveness, productivity, price competitiveness and access to resources. Performance measures, which focus on the outcome of the operation, e.g. export market share, balance of trade, export growth and profitability. Process measures, which explain the management of the operation, e.g. government policies, commitment to international business and management relations, etc. The process measures require a qualitative study of management processes (i.e. the effectiveness of corporate and divisional decision-making) at the firm level and government management of the economy at the national level, which is beyond the scope of this study (Pascucci, 2018). Alternatively, it requires detailed micro-firm data which is not readily accessible for the selected countries.

\subsection{Measures of competitiveness at the farm-level}

In the previous literature, farm-level competitiveness papers have used indicators such as partial productivity measures, namely, milk yield per cow $(\mathrm{kg})$, milk solids per cow (kg), stocking rate (LU/ha), milk production per hectare $(\mathrm{kg})$, milk solids per hectare $(\mathrm{kg})$, milk production per labour unit (tonne) and accountancy-based indicators. These partial productivity measures help to track the input costs (total costs per $\mathrm{kg}$ milk solids) and profitability (total costs as a percentage of dairy output) (Boyle, 2002; Groeneveld et al., 2016; Thorne et al., 2017). In these studies, Ireland was considered as a competitive milk producer based on cash costs as a percentage of output or per kg milk solids but was ranked in the bottom three when it came to partial productivity indicators and total economic costs of production. The high seasonality of milk production in Ireland has limited efficiency in the processing industry, which requires a constant supply of milk throughout the year to maximise efficiency (National Milk Agency, 2019). Donnellan et al. (2011) projected that there would be an increase in milk production, farm sizes and processing facilities in Ireland post-quota, which would help drive competitiveness. On the other hand, Viira et al. (2015) found that Ireland was the most significant country within the EU in 2014 with the highest import of raw milk, which was processed, i.e. $6 \%$ of the processed raw milk. 


\subsection{Measures of competitiveness at the trade-level}

Previous export competitiveness studies have computed indicators such as export and import price growth rates, export-to-import ratio, net export market share (NXMS), RCA, relative import advantage (RMA), relative trade advantage (RTA) or revealed competitiveness (RC) and NRCA (Yu et al., 2009; Viira et al., 2015; Suwannarat, 2017). Price and quality competitiveness were used to analyse the industry or product performance and potential in the market (Buckley et al., 1988). If the quality of the product is a crucial component in the market as in the dairy industry, price may be considered as an approximate indicator for quality because there is no quantitative data on product quality. Low prices would indicate low-quality products.

There has been an increasing number of export competitiveness studies in other industries, using the RCA as the primary indicator. Examples include; the agriculture and manufacturing sector in Pakistan (Abbas and Waheed, 2017), the tuna industry in Thailand (Kuldilok et al., 2013), the wine industry in the EU (Balogh and Jámbor, 2017) and the coffee roasting industry in Italy (Pascucci, 2018). In the dairy industry, Bojnec and Ferto' (2014) used the RCA measure and found that Ireland was one of the few countries that had a competitive advantage in the world market for total dairy products from 2000 to 2011. However, previous research has focused on exports only and was narrow on the measures that considered imports. Import competitiveness is very broad and has aspects beyond the scope of this study, i.e. import processes and its management. It requires data which is not readily available.

\section{Data sources and methodology}

\subsection{Data sources}

4.1.1 Farm-level. For the analysis presented here, the data sources were the European Commission's Farm Accountancy Data Network (FADN) [i.e. Type of farming (45)specialist dairy farms] and Eurostat for fat and protein content, to analyse the largest EU specialist milk producers (i.e. Belgium, Germany, France, Denmark, Italy, The Netherlands and the UK) and to calculate partial productivity and accountancy-based indicators. The countries were selected based on the findings by studies such as Thorne and Fingleton (2006), Bojnec and Fert”̋ (2014), Giles (2015) and Thorne et al. (2017). Moreover, these countries compete with Ireland in terms of production and trade in the world market. They also play a significant role in the agricultural policy arena (Boyle, 2002). The data was obtained from the European Central Bank (ECB) for the annual nominal interest rate and Worldwide Inflation Data (WID) for the annual inflation rate, which was used to calculate the annual real interest rate.

4.1.2 Trade-level. The data was gathered from FAOstat for trade competitiveness indicators (2012-2017) which included dairy products (butter, cheese, skimmed milk, dried skimmed milk, dried whole milk and whole fresh milk) and agricultural imports and exports within the EU and in the world. The data for the exchange rate was also secured from FAOstat.

\subsection{Methods}

4.2.1 Farm-level. An average of three years (short-term) pre (2012-2014) and post (20152017) quota was calculated for all variables. Farm-level data was used to compute partial productivity measures and accountancy-based indicators, following Thorne et al. (2017). Total cash costs include all specific costs directly incurred in the production of a given commodity (e.g. fertiliser, feedstuffs, seeds etc.), external factors (e.g. wages, rent and interest paid) and farming overheads (e.g. machinery and building current costs, energy and contract work etc.). The total economic costs include all cash costs plus depreciation and imputed opportunity costs for family labour, equity capital and owned land. Total costs and 
$\mathrm{CR}$ 32,7

cash costs were expressed as a per kg milk solids to account for the differences in milk fat and protein, and as a percentage of dairy output to account for differences in milk prices, which depicts the variation in profitability across countries or resilience of countries to changes in milk prices (Boyle, 2002; Thorne et al., 2017). According to Buckley et al. (1988), costs enable a comparison between firms/farms using different methods of foreign market servicing.

4.2.2 Trade-level. Based on the theory of comparative advantage, a country specialises and exports products for which it has a comparative advantage (Viira et al., 2015; Abbas and Waheed, 2017). According to Latruffe (2010), RCA, which is Vollrath's modified version of the Balassa index is based on exports only. RCA measures a country's export market share of a commodity relative to its total agricultural exports in the world markets. An RCA index greater than one indicates that the country has a comparative advantage in exports of dairy products and has higher competitiveness in the world agricultural market. The revealed comparative import advantage (RMA) is based on imports only, and an RMA index less than one indicates a comparative advantage and thus higher competitiveness as the country can meet its domestic demand with minimal or no dairy imports relative to other agricultural imports in that country. A country is considered to have import competitiveness when it is not dependent on imports (net exporter) to meet domestic demand or when it can keep its imports minimal.

In the literature, the RCA indicator has been criticised for three main reasons (Yu et al., 2009; Suwannarat, 2017). Firstly, countries cannot be compared to each other using the RCA, and it can only compare the trends over a period for each country. Secondly, the RCA index is not symmetric (between -1 to 1 ) and the mean is not fixed, hence the RCA index can range from one to infinity, making it difficult to compare countries. Even though some studies have used the revealed competitiveness $(\mathrm{RC})$ index, which is the difference between $\log$ RCA and RMA. This has a limitation as the outcome is not always symmetric, for example, if RCA is 3 and RMA is 0.2 the result is 1.2 which is outside that range. Thirdly, the RCA does not account for the size of the country and commodity market in the world. To address the limitations of the RCA, the NRCA indicator is used.

According to Yu et al. (2009), the NRCA index measures the degree of deviation of a country's actual exports from its comparative-advantage-neutral situation in terms of its relative scale concerning the world export market. An NRCA index greater than zero (comparative-advantage neutral point) (or NRCA $<0$ ) indicates that the country has a comparative advantage (or disadvantage). The index shows the dairy products that the country specialises in and how it competes in those products with other countries. The higher (or the lower) the NRCA score is above zero, the greater the comparative advantage (or disadvantage) for a county. The country with the highest NRCA score is the most competitive. No country can have a comparative advantage (or disadvantage) in all products based on the relative nature of comparative advantage or the assumption that the available resources which are shared across products are limited or held constant. Therefore, the sum of a country's and the sum of a product's NRCA scores equals to zero, which means that when a country gains a comparative advantage in producing a dairy product, other countries lose comparative advantage in that dairy product.

The NRCA calculates competitiveness from the comparative-advantage neutral point for each country which enables country and dairy products comparisons and ranking. The NRCA considers both the country's market share of all commodities in the world export market and the specific commodity's market share in the world market. The size of the country and dairy product markets is important for distinguishing specialisation or competitiveness in big and small countries and their comparable dairy products. For 
example, it could be expected that more prominent countries may favour diversification because of the economies of scale, and smaller countries may choose to specialise more in a few products with more focus on niche markets. Export competitiveness measures such as the NRCA index face a common criticism which is that they ignore the import indicators and as a result, the net export market share (NXMS) indicator is used (Martin et al., 1991; Fetscherin et al., 2012; Pascucci, 2018). The market share indicator looks at the absolute performance of an industry vis-à-vis its European or world competitors. Therefore, the use of the net export market share indicator complements the NRCA indicator.

Table 1 specifies the indicators used in this study to enrich the export competitiveness analysis and augment the NRCA indicator. Given that countries do not use similar technologies and factors of production, this may influence the trade patterns and specialisation. Hence, the value rather than the quantity approach is considered suitable for this study to calculate the NRCA index. The export and import price and quantity changes or growth rates were calculated to capture the significance of the trends. According to Fetscherin et al. (2012), Suwannarat (2017) and Pascucci (2018), export growth in each industry and country implies a greater degree of competitiveness. The export-to-import ratio

\begin{tabular}{|c|c|}
\hline Measure & Calculation/equation \\
\hline \multirow{2}{*}{ Export [or import] price $€ / \mathrm{kg}$} & Export [or import] value \\
\hline & $\overline{\text { Export }[\text { or import }] \text { quantity }}$ \\
\hline \multirow{2}{*}{ Export-to-import ratio (export quality) } & Export Price $(€) / \mathrm{kg}$ \\
\hline & $\overline{\operatorname{Import} \operatorname{Price}(€) / \mathrm{kg}}$ \\
\hline \multirow{2}{*}{ Relative change or growth rate } & Export $[$ or import $]$ price $($ post - pre $)$ \\
\hline & Export $[$ or import $]$ price pre \\
\hline $\begin{array}{l}\text { Export [or import] market share } \\
\text { (EMS) [or IMS]- value terms }\end{array}$ & $\left(\frac{\text { Country dairy exports }[\text { or imports }]}{\text { World dairy exports }[\text { or imports }]}\right) \times 100$ \\
\hline Net export market share (NXMS) & Export market share $(\%)$ - Import market share $(\%)$ \\
\hline \multirow[t]{6}{*}{$\begin{array}{l}\text { Normalised revealed comparative export } \\
\text { advantage (NRCA)- value terms* }\end{array}$} & $\left(\frac{\text { Country total dairy products exports }}{\text { World agricultural exports }}\right)-$ \\
\hline & $\left(\frac{\text { Country agricultural exports }}{\text { World agricultural exports }}\right)$ \\
\hline & $\left(\frac{\text { World total dairy products exports }}{\text { Wolrd agricultural exports }}\right)$ (i) \\
\hline & $\left(\frac{\text { Country dairy product exports }}{\text { World total dairy products exports }}\right)-$ \\
\hline & $\left(\frac{\text { Country total dairy products exports }}{\text { World total dairy products exports }}\right)$ \\
\hline & $\left(\frac{\text { World dairy product exports }}{\text { Wolrd total dairy products exports }}\right)$ (ii) \\
\hline
\end{tabular}

Notes: *For total dairy products, the first equation (i) is used and for individual dairy products (i.e. butter, cheese, skimmed milk, skimmed dried milk, whole dried and whole fresh milk), the second equation (ii) is used
Irish dairy industry 
$\mathrm{CR}$

32,7

10

is used for assessing product quality. A ratio greater than one indicates that exports are more expensive, and thus of higher quality than imports. The net export market share shows the difference between the export and import market share of the dairy products. It reveals the competitive position of a country in the international market for a given sector (Martin et al., 1991; Suwannarat, 2017). A higher index suggests a higher potential of that country in that industry and a negative value indicates that the country is a net importer in that sector or product.

These measures are used to rank the country positions and trends. Two short term periods were used to examine relative performance pre and post policy change. According to Fetscherin et al. (2012), using longitudinal data enables one to look at the historical change of export competitiveness for various industries and countries. This helps to overcome the need for analysing the predictive values by focusing on trends instead, which are useful for strategic decision making (Pascucci, 2018). Whilst the change in performance indicators do not prove causality with the policy change. The change in position would suggest a significant impact in the time period examined, during which the policy change was a significant structural event.

\section{Results}

\subsection{Farm-level competitiveness}

Table 2 presents productivity measures such as milk yield and solids per cow, and stocking rate per hectare. Ireland had the lowest milk yield per cow pre- and post-quota, but it had the second-highest growth rate at $6.9 \%$. The situation with milk solids was similar, Ireland had the lowest level but had the highest growth rate of $10 \%$. The UK declined the most in both milk yield $(1.5 \%)$ and solids $(0.2 \%)$ per cow post-quota. Growth in milk solids, which is influenced by farming practices, leads to improvements in the efficiency of the dairy processing industry (Viira et al., 2015) as milk pricing models tend to place value on fat and protein content. Ireland had the highest stocking rate increase of $5 \%$ and Italy had the highest decline of $11 \%$.

Table 3 provides the land and labour partial productivity indicators pre- and post-quota. Ireland had the highest growth rate at $12 \%$ for milk production per hectare, $16 \%$ for milk solids per hectare and $19 \%$ for milk production per labour unit. Thorne et al. (2017) also found similar partial productivity results in a more limited period post-quota. Generally, most countries improved their partial productivity indicators post-quota as highlighted in Tables 2 and 3, with Ireland showing the most growth potential. Italy was the only country amongst the countries examined to exhibit negative growth rates post-quota for milk production $(10 \%)$ and solids $(7 \%)$ per hectare.

\begin{tabular}{lccccccccc}
\hline & \multicolumn{3}{c}{ Milk yield/cow (kg) } & \multicolumn{3}{c}{ Milk Solid/cow (kg) } & \multicolumn{3}{c}{ Stocking rate (LU/ha) } \\
Country & Pre & Post & Change(\%) & Pre & Post & Change(\%) & Pre & Post & Change(\%) \\
\hline BEL & 7131 & 7501 & 5.2 & 533 & 563 & 5.6 & 2.3 & 2.4 & 4.3 \\
DAN & 8926 & 9563 & $\mathbf{7 . 1}$ & 691 & 745 & 7.9 & 2.2 & 2.3 & 4.6 \\
DEU & 7536 & 7597 & 0.8 & 567 & 582 & 2.6 & 1.9 & 1.9 & 1.7 \\
FRA & 6840 & 6856 & 0.2 & 504 & 507 & 0.6 & 1.4 & 1.5 & 3.4 \\
IRE & 5365 & 5735 & 6.9 & 394 & 435 & $\mathbf{1 0 . 2}$ & 2.0 & 2.1 & $\mathbf{5 . 0}$ \\
ITA & 6072 & 6163 & 1.5 & 434 & 458 & 5.5 & 3.4 & 3.0 & $\mathbf{- 1 1 . 4}$ \\
NED & 7969 & 8334 & 4.6 & 630 & 660 & 4.9 & 2.5 & 2.5 & -0.3 \\
UKI & 7327 & 7219 & $\mathbf{- 1 . 5}$ & 535 & 533 & $-\mathbf{0 . 2}$ & 2.1 & 2.1 & 0.3
\end{tabular}

Sources: Authors' calculations based on FADN; Eurostat; ECB and WID data set 
Milk prices are a critical influencing factor in dairy farmer behaviour which can influence investments to increase production and improve productivity. Donnellan et al. (2011) noted that the Irish farm milk price is primarily determined by dairy commodity prices on the EU market. Post-quota, milk prices declined for all countries, in Ireland prices fell by $13 \%$ compared to the UK which fell the most by $15 \%$. The price decline in France was the smallest at $7 \%$. Irish dairy farmers had the second-highest net farm income on average (after Italy) post-quota, with the highest growth rate of $18 \%$. This was significant given that income declined in most countries except for Germany and Italy as demonstrated in Table 4. Dairy farmers in The Netherlands experienced the largest net income decline (28\%). Ireland had the highest growth in dairy cows of $9 \%$ with The Netherlands declining the most by 1.6\%. Groeneveld et al. (2016) argued that in The Netherlands, the policy change would lead to no detrimental changes on the number of cows kept by the smallest farm type. The Irish total utilised agricultural area growth rate remained stagnant, compared to Italy which increased the most by $13 \%$ and The Netherlands which fell the most by $5 \%$.

According to Buckley et al. (1988), the lower the costs a firm/industry incurs, the more competitive they will be. Figure 4 shows the total costs (cash and economic) per $\mathrm{kg}$ of milk solids pre and post-quota and country rankings based on total cash costs. Similarly, Figure 5 provides the total costs as a percentage of market-based dairy output pre and post-quota and total cash cost rankings. In general, total costs for milk solids fell for all the countries.

\begin{tabular}{lrrrrrrrrr}
\hline & \multicolumn{3}{c}{ Milk production (kg/ha) } & \multicolumn{3}{c}{ Milk solids(kg/ha) } & \multicolumn{3}{c}{ Milk production/labour unit } \\
Country & \multicolumn{1}{c}{ Pre } & Post & Change(\%) & Pre & Post & Change(\%) & Pre & Post & Change(\%) \\
\hline BEL & 16,187 & 17,753 & 9.7 & 1,210 & 1,331 & 10.1 & 337,645 & 378,299 & 12.0 \\
DAN & 19,398 & 21,753 & 12.1 & 1,502 & 1,695 & 12.9 & 779,605 & 805,361 & $\mathbf{3 . 3}$ \\
DEU & 14,415 & 14,778 & 2.5 & 1,084 & 1,131 & 4.4 & 333,101 & 353,362 & 6.1 \\
FRA & 9,675 & 10,031 & 3.7 & 713 & 741 & 4.0 & 294,940 & 305,551 & 3.6 \\
IRE & 10,764 & 12,075 & $\mathbf{1 2 . 2}$ & 791 & 915 & $\mathbf{1 5 . 6}$ & 320,612 & 382,377 & $\mathbf{1 9 . 3}$ \\
ITA & 20,874 & 18,776 & $-\mathbf{1 0 . 1}$ & 1,492 & 1,395 & $-\mathbf{6 . 5}$ & 230,587 & 250,155 & 8.5 \\
NED & 20,261 & 21,110 & 4.2 & 1,601 & 1,673 & 4.5 & 491,773 & 518,113 & 5.4 \\
UKI & 15,237 & 15,064 & -1.1 & 1,112 & 1,113 & 0.1 & 451,124 & 476,691 & 5.7
\end{tabular}

Sources: Authors' calculations based on FADN; Eurostat; ECB and WID data set
Irish dairy industry

11
Table 3

Land and labour productivity indicators pre- and post-quota

\begin{tabular}{|c|c|c|c|c|c|c|c|c|c|c|c|c|}
\hline \multirow[b]{2}{*}{ Country } & \multicolumn{3}{|c|}{ Milk price (€/100 kg) } & \multicolumn{3}{|c|}{$\begin{array}{c}\text { Total utilised agric. } \\
\text { area (ha) }\end{array}$} & \multicolumn{3}{|c|}{ Dairy cows (LU) } & \multicolumn{3}{|c|}{ Farm net income $(€)$} \\
\hline & y Pre & Post & Change $(\%)$ & ) Pre & Post & Change $(\%)$ & Pre & Post C & hange $(\%)$ & Pre & Post & Change $(\%)$ \\
\hline BEL & 34.47 & 29.89 & -13 & 53.6 & 54.1 & 0.9 & 66.6 & 72.3 & 8.6 & 65,025 & 55,828 & -14 \\
\hline DAN & 37.44 & 32.25 & -14 & 159.9 & 158.5 & -0.9 & 168.3 & 166.4 & -1 & 57,355 & 45,710 & -20 \\
\hline DEU & 34.77 & 31.12 & -11 & 72.1 & 72.1 & 0.1 & 61.2 & 63.2 & 3 & 47,287 & 47,498 & 0.4 \\
\hline FRA & 34.36 & 31.84 & -7 & 91.5 & 91.5 & 0.1 & 57.1 & 59.5 & 4 & 36,968 & 32,432 & -12 \\
\hline IRE & 36.09 & 31.42 & -13 & 59.4 & 59.4 & 0 & 67.3 & 73.5 & 9 & 61,808 & 73,092 & 18 \\
\hline ITA & 38.48 & 34.56 & -10 & 29.5 & 33.3 & 13 & 53.7 & 55.8 & 4 & 88,625 & 89,812 & 1 \\
\hline NED & 37.57 & 32.31 & -14 & 53.9 & 51.3 & -5 & 93.5 & 92.0 & -1.6 & 72,304 & 51,991 & -28 \\
\hline UKI & 35.98 & 30.53 & -15 & 109.5 & 112.7 & 3 & 130.9 & 135.4 & 3.5 & 77,866 & 57,940 & -26 \\
\hline
\end{tabular}

Sources: Authors' calculations based on FADN; Eurostat; ECB and WID data set

Table 4.

Raw milk price and farm income pre- and post-quota 
$\mathrm{CR}$

32,7

12

Figure 4 .

Total costs per kg milk solids and total cash cost ranking pre- and post-quota

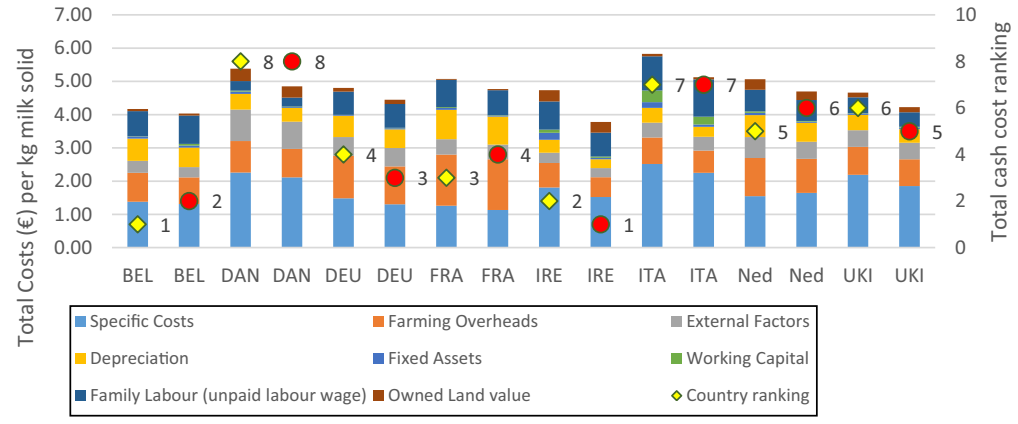

Sources: Authors' calculations based on FADN; Eurostat; ECB and WID data set

The results for total costs as a percent of dairy output were mixed, which is expected given the change in milk price post-quota. Total costs and total cash costs for milk solids fell the most in Ireland by $20 \%$ and 16\%, respectively, moving from third to first position and second to first position, respectively. The lowest total costs and total cash costs recorded post-quota were in Ireland at $€ 3.78 / \mathrm{kg}$ and $€ 2.39 / \mathrm{kg}$, respectively. By contrast, Italy and Denmark had the highest total cost (€5.13/kg) and total cash cost (€3.79/kg) postquota, respectively. Consequently, Ireland was ranked first as the most competitive country post-quota for both total costs and total cash costs per $\mathrm{kg}$ of milk solids, Belgium lost its rank to Ireland becoming second.

Ireland ranked third, pre $(55 \%)$ and post $(56 \%)$ quota, for total cash costs as a percentage of dairy output with the third-lowest growth in total cash costs of $0.5 \%$. Belgium $(51 \%)$ and Italy $(50 \%)$ (declined the most by $3.7 \%$ ) ranked first, respectively, pre- and post-quota. Ireland had the second-highest drop of $4.4 \%$ in total costs, which led to a rise from fourth to the second position with total costs of $88 \%$ post-quota after Italy $(78 \%)$. Denmark had the highest total cost (102\%) and total cash costs $(80 \%)$ post-quota. The Irish land and family labour costs per kg milk solids slightly declined post-quota, which were important for the dairy farmers' ability to adapt and expand milk production efficiently. Despite that, Ireland continued to have the third-highest family labour costs as a percent of dairy output and milk

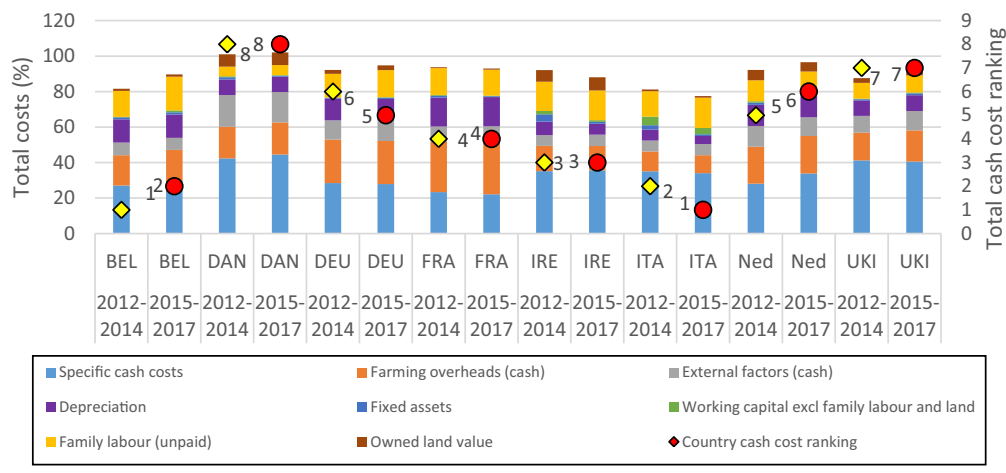

Sources: Authors' calculations based on FADN; Eurostat; ECB and WID database

\section{Figure 5.}

Total costs as a percentage of dairy output and total cash cost ranking 
solids post-quota. Donnellan et al. (2011)also observed that Ireland relied more on family labour than hired labour which kept the imputed costs high.

Irish dairy industry

\subsection{Trade competitiveness based on normalised revealed comparative advantages ranking} across countries and dairy products

The strength of the dairy sector in a country is demonstrated by the NRCA (Bojnec and Ferto", 2014) and the market share. Figure 6 depicts the competitiveness ranking across countries and

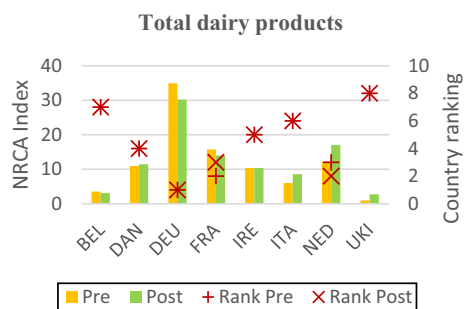

Cheese

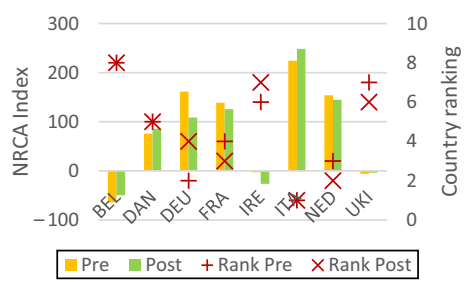

Skimmed dried milk

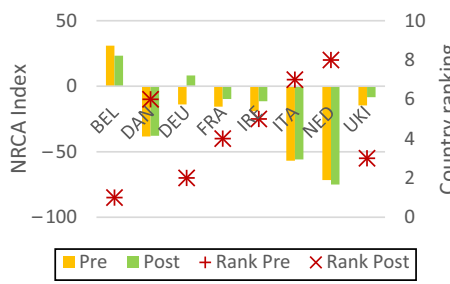

Whole fresh milk

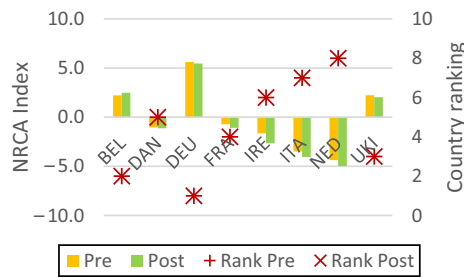

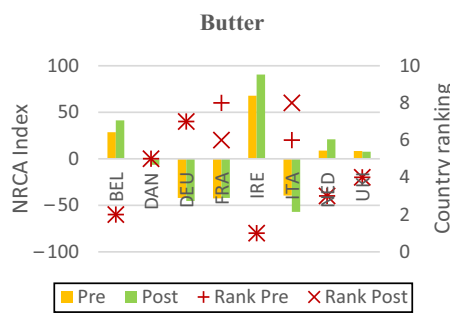

Skimmed cow milk

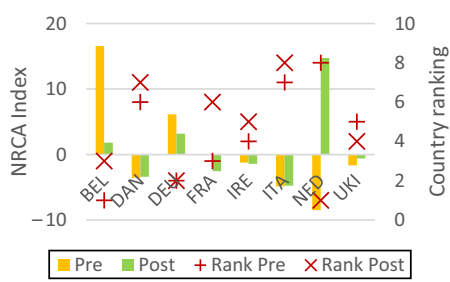

Whole dried milk

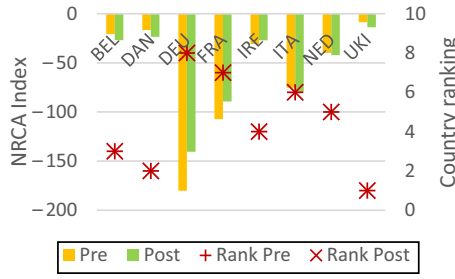

Whey

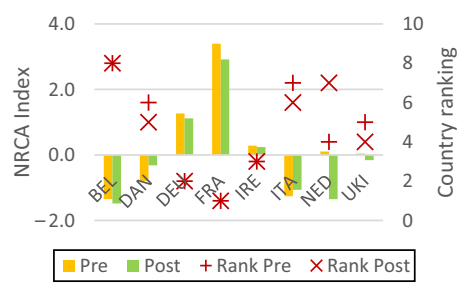

Figure 6. NRCA competitiveness ranking across countries and dairy products

Source: Authors' calculations based on FAOstat database 
$\mathrm{CR}$ 32,7

dairy products based on the NRCA index pre- and post-quota. Overall, the rankings for countries changed in most dairy products except powders and whole fresh milk. Based on total dairy products, Ireland was ranked at number five amongst the countries examined preand post-quota. Its competitiveness remained relatively unchanged at just 0.01 points. The Netherlands increased the most by 4.9 points and Germany declined the most by 4.7 points.

Focusing on individual dairy products, Ireland was ranked first in butter pre- and postquota and showed the strongest growth of 22.7 points in competitiveness followed by Belgium at 12.7 points. Italy declined the most by 17.5 points and lost its sixth position to France. Ireland had the highest net export market share (NXMS) of 10.6\% for butter postquota, but the growth rate was the fourth highest at $10.9 \%$ (Figure A2 in the appendix). The butter prices indicated that Ireland was exporting (€3.51/kg) very high-quality butter compared to what was imported (€2.86/kg). Moreover, Irish butter was the only dairy product that did not experience a shift in the supply curve, but it was the only product that had a shift (rightward) in the demand curve (Figure A1 in the appendix). There was a rightward shift in the supply curve for most Irish dairy products except whole fresh milk which had an opposite shift. In this case, the supply shifts can mainly be attributed to the changes in policy and prices of factors of production, amongst other factors.

Based on the NRCA index, whey from Ireland was ranked third pre- and post-quota and was the second most competitive dairy product within Ireland, even though it slightly dropped in competitiveness by 0.4 points. Denmark increased the most by 4.8 points and The Netherlands declined significantly by 14.6 points. Compared to other Irish dairy products, whey had the greatest reduction of $33 \%$ in export $(€ 1.47 / \mathrm{kg})$ to import $(€ 1.56 / \mathrm{kg})$ quality ratio and lost its third position for net export market share post-quota to Denmark. In Ireland, the NRCA index fell for most dairy products such as cheese (23.3 points - second highest fall in this category after Germany at 52.5 points), skimmed cow milk ( 0.2 points), whole fresh milk (10.1 points - with most significant decline in this category) and whey. Whereas it increased in products such as butter, skimmed (7.6 points) and whole (3.8 points) dried milk post-quota. Germany had the highest rise in competitiveness for skimmed (22.1 points) and whole (39.7 points) dried milk. Ireland had the highest growth rate in quantity exported for skimmed (59\%) and whole (44\%) dried milk compared to other countries, even though they still operate at a comparative disadvantage.

The general ranking position of Irish products remained unchanged post-quota, except for cheese and skimmed cow milk which lost their competitiveness positions to the UK. The least competitive dairy products from Ireland compared to other countries were cheese (7th) and whole fresh milk (6th) post-quota. The competition in the cheese market was much stronger than it was in butter. The net export market share for cheese was the least positive at $2 \%$ post-quota. However, Ireland had the highest quantity of cheese produced compared to butter post-quota. For whole fresh milk, Ireland had the highest reduction (77\%) in export quantity and a further deficit in net export market share of $3.5 \%$ post-quota. Irish whole fresh milk was more valuable abroad $(€ 0.71 / \mathrm{kg}$ ) than it was domestically $(€ 0.31 / \mathrm{kg})$. This resulted in high growth in imports by processors/creameries.

\section{Discussions and policy implications}

\subsection{Farm-level competitiveness}

The decline in Irish milk prices coupled with the growth in the number of cows and the high growth in net farm income suggests that the quota abolition shifted the supply curve downwards to a new equilibrium point. After quota abolition, the Irish farmers produced more and reduced costs of production through economies of scale. As noted by Boyle (2002), high productivity may compensate for relatively low output prices. In fact, Ireland had been 
producing above the imposed quota before 1984 and was not producing at its most effective level during the quota phase (Jansik et al., 2014; Donnellan et al., 2015; Läpple and Sirr, 2019). Farmers adjust their practices regularly to improve productivity and to remain resilient to negative price effects. For example, Ireland improved its cost competitiveness ranking postquota and was ranked first with the lowest total costs and total cash costs per $\mathrm{kg}$ milk solids. Despite reductions in milk price, Ireland retained its position of third place for total cash costs as a percentage of dairy output post-quota. Furthermore, Ireland had the secondlowest total costs post-quota with the second-highest reduction in total costs as a percentage of dairy output. This has positive implications for the potential of Irish farms in the future, even in comparison to the competitor countries.

Based on the partial productivity indicators, it can be argued that Ireland exploited the opportunity to expand production post-quota more than other countries. This expansion was achieved through productivity gains. However, despite the significant expansion, there were only marginal changes in land and labour size, suggesting that farms may be approaching their productive limit. If production continues to increase in Ireland, the demand for more land will also increase in the long run. Government intervention will be required to ensure proper land regulation policies. According to Dillon et al. (2008), if land access and fragmentation challenges remain unchanged, more dairy farmers will be likely to consider a combination of grazing and indoor high input farming systems to expand their farming operation and remain competitive. The demand for feed will more likely increase as well because more land may not be available. Therefore, the increase in the number of cows may have severe environmental implications if not monitored accordingly in the future. The need for the Irish government and dairy stakeholders to increase the availability of farm labour and their efficiency to replace family labour remains justified post-quota, as outlined in the Food Wise 2025 strategy. Improved availability and productivity of factors of production, such as land and labour, can further enhance the competitiveness position of Ireland in the long run. This is necessary under volatile milk prices and stringent environmental regulations.

\subsection{Trade-level competitiveness}

Whilst Irish dairy products such as butter and powders indicated growth potential in competitiveness, other dairy products such as cheese, whey, skimmed and whole cow milk became less competitive post-quota. Post-quota, Ireland had the highest quantity of cheese produced compared to butter, but there was high competition from other countries for cheese. Cheese had a lower value compared to butter in Ireland. This resulted in a drop in cheese ranking and specialisation for Ireland post-quota. However, low net market share and poor competitiveness ranking does not always imply low profitability, this depends on the country's strategic positioning. The strategic goals that promote innovation for expansion of the sector in the Food Wise 2025 suggests that Ireland seeks to be a unique player in the international market. This may be more sustainable in the future for a small country ( $\mathrm{Yu}$ et al., 2009). According to Porter (1998), some countries want to be the best or number one and some want to be unique in the market. Countries with the same products compete by imitation and market share, which is a zero-sum game. In contrast, countries pursuing a uniqueness strategy focus on profits and compete using innovation, which is a positive-sum.

According to Buckley et al. (1988), strategic access to a key input for processing, i.e. raw milk, may be a source of competitiveness. The decline in whole fresh milk exports was motivated by the focus on the value creation strategy which promotes exporting high-value products and importing low-value products. This trend has left the Irish raw milk market susceptible to international competitors. The need for sustainable growth of the processing industry for Ireland to remain competitive in the global market is difficult to question. Nonetheless, how that growth
Irish dairy industry 
$\mathrm{CR}$ 32,7

16

is achieved needs to be monitored. The lack of a monitoring system could present a challenge for local dairy farmers because processors could start offering lower prices for raw milk in future, on par with world markets, especially if the world prices continue to drop (Jansik et al., 2014). The location of Northern Ireland where raw milk is imported from is an advantage to Ireland due to proximity which reduces the transport costs and trading rigidities. However, in the long run, the cheap imports can undermine the benefit of cost competitiveness of the Irish milk at farm-level delivered to processors. This highlights the importance of evaluating farm- and trade-level data simultaneously by policymakers to ensure that Irish farmers are protected and rewarded for improving their productivity.

There is a need for ensuring secure access to raw materials within the value chain to contribute to the economies of scale for the country. Given the land limitations at farm-level, better technology and trade agreements will be needed to improve and maintain competitiveness in the long run. The rise in raw milk imports used to produce Irish dairy products may eventually raise some ethical issues such as the rules of origin (traceability) which will need to be addressed by policy makers to protect the "produced in Ireland" brand image (Pascucci, 2018). Product differentiation is essential for Ireland to compete and reach new markets. The growth in competitiveness of powders was in line with the Food Wise 2025 objectives to reach developing countries and diversifying its markets. However, more growth is still needed to ensure that Ireland has a comparative advantage in powders. According to Buckley et al. (1988), on a short time horizon the highly competitive products earning high margins may compensate for uncompetitive products. The ability of the Irish dairy industry to generate and maintain competitive advantages and net export market shares highlights the strong competitiveness position that it has relative to its competitors.

\section{Conclusions}

The unique feature of this study was the use of the competitiveness assessment approach to provide insights for value chain decision making in the dairy industry. This was achieved by identifying trends and rankings and comparing Ireland's competitiveness position to other countries pre- and post-quota. The analysis of different dairy products, which allowed for the comparison of countries, provided deeper understanding of the dairy industry. The findings are useful for all the selected countries in the EU. The evidence suggested that Ireland had the most significant rates of farm production expansion, overall, relative to other countries post-quota. However, this farm-level expansion was insufficient to meet the growing demand for the export of dairy products, even domestic demand. This led to strong growth in liquid milk imports postquota, highlighting the interdependence between farm and trade-level competitiveness.

To date, trade-level analysis for the dairy sector has been relatively limited, as previous analyses have typically aggregated processed dairy products despite the high variation in price, quantity, markets and strategies used per product. This aggregated approach has not been particularly useful for comparing countries or for informing decision-making. Despite Ireland being a small country, it remained competitive for dairy products, such as butter and whey in terms of EU rankings, and butter and powders in terms of competitiveness growth. Hence, the differences in the competitiveness of dairy products highlighted the importance of disaggregating dairy products to allow for specialised cross-country analysis. Research on individual dairy products is essential given the changes in specialist country behaviours. This study has been the first of its kind towards this direction.

\section{Future research agenda}

Future research must analyse the factors influencing the competitiveness of the Irish dairy products. Also, identify the factors that influence their export demand and supply in the 
long run. Highlighting industry opportunities and threats as well as exploring the influence of key competitors in the target markets (in both developed and developing countries) using long run data and econometric techniques for analysis. This will be crucial to understanding and improving the overall competitiveness of the Irish dairy industry in the long run.

\section{References}

Abbas, S. and Waheed, A. (2017), "Trade competitiveness of Pakistan: evidence from the revealed comparative advantage approach", Competitiveness Review: An International Business Journal, Vol. 27 No. 5, pp. 462-475.

Balogh, J.M. and Jámbor, A. (2017), "The global competitiveness of European wine producers", British Food Journal, Vol. 119 No. 9, pp. 2076-2088.

Bojnec, S. and Fert", I. (2014), "Export competitiveness of dairy products on global markets: the case of the European Union countries", Journal of Dairy Science, Vol. 97 No. 10, pp. 6151-6163.

Boyle, G.E. (2002), “The competitiveness of Irish agriculture”, Report for the Department of Agriculture and Food, The Irish Farmers Journal, Dublin.

Buckley, P.J., Pass, C.L. and Prescott, K. (1988), "Measures of international competitiveness: a critical survey", Journal of Marketing Management, Vol. 4 No. 2, pp. 175-200.

Dillon, P., Hennessy, T., Shalloo, L., Thorne, F. and Horan, B. (2008), "Future outlook for the Irish dairy industry: a study of international competitiveness, influence of international trade reform and requirement for change", International Journal of Dairy Technology, Vol. 61 No. 1, pp. 16-29.

Donnellan, T., Hennessy, T., Keane, M. and Thorne, F. (2011), Study of the International Competitiveness of the Irish Dairy Sector at Farm Level, Teagasc, Dublin.

Donnellan, T., Hennessy, T. and Thorne, F. (2015), The End of the Quota Era: A History of the Irish Dairy Sector and Its Future Prospects, Teagasc, Athenry.

Eurostat (2019), "Milk and milk product statistics", Statistics Explained. URL, available at: https:/ec. europa.eu/eurostat/statisticsexplained/ (accessed 02/10/2019).

Fetscherin, M., Alon, I., Johnson, J.P. and Pillania, R.K. (2012), "Export competitiveness patterns in Indian industries", Competitiveness Review, Vol. 22 No. 3, pp. 188-206.

Giles, J. (2015), "Change in the EU dairy sector post quota: more milk, more exports and a changing farmer profile", EuroChoices, Vol. 14 No. 3, pp. 20-24.

Groeneveld, A., Peerlings, J., Bakker, M. and Heijman, W. (2016), "The effect of milk quota abolishment on farm intensity: shifts and stability", Njas - Wageningen Journal of Life Sciences, Vol. 77, pp. 25-37.

Jansik, C., Irz, X. and Kuosmanen, N. (2014), Competitiveness of Northern European Dairy Chains, MTT: Agri-food Research, Finland. Publications 116.

Kuldilok, K.S., Dawson, P.J. and Lingard, J. (2013), "The export competitiveness of the tuna industry in Thailand", British Food Journal, Vol. 115 No. 3, pp. 328-341.

Läpple, D. and Sirr, G. (2019), "Dairy intensification and quota abolition: a comparative study of production in Ireland and The Netherlands", EuroChoices, Vol. 18 No. 3, pp. 26-31.

Latruffe, L. (2010), Competitiveness, Productivity and Efficiency in the Agricultural and Agri-Food Sectors, OECD Food, Agriculture and Fisheries Papers, No. 30, OECD Publishing, Paris.

Martin, L., Westgren, R. and van Durren, E. (1991), “Agribusiness competitiveness across national boundaries", American Journal of Agricultural Economics, Vol. 73 No. 5, pp. 1456-1464.

National Milk Agency (2019), "Annual report and accounts 2019”, Holly Park Studio, Holly Park Avenue, Blackrock, Co. Dublin, available at: http:/nationalmilkagency.ie/uploads/files/ annualreports/2029/NMA-annual-report2019.pdf (accessed 22/08/2020).

Pascucci, F. (2018), “The export competitiveness of Italian coffee roasting industry", British Food Journal, Vol. 120 No. 7, pp. 1529-1546. 
Porter, M.E. (1998), Competitive Strategy: techniques for Analysing Industries and Competitors, The Free Press, New York, NY.

Suwannarat, P. (2017), "Ascertaining the competitiveness of Thai exports to PRC", Competitiveness Review: An International Business Journal, Vol. 27 No. 3, pp. 275-299.

Thorne, F.S. and Fingleton, W. (2006), "Examining the relative competitiveness of milk production: an Irish case study (1996 - 2004)", Journal of International Farm Management, Vol. 3 No. 4, pp. 1-13.

Thorne, F., Gillespie, P.R., Donnellan, T., Hanrahan, K., Kinsella, A. and Läpple, D. (2017), The Competitiveness of Irish Agriculture, Teagasc, Dublin.

Viira, A.-H., Omel, R., Värnik, R., Luik, H., Maasing, B. and Põldaru, R. (2015), “Competitiveness of the Estonian dairy sector, 1994-2014”, Journal of Agricultural Science, Vol. 2 No. 26, pp. 84-105.

Yu, R., Cai, J. and Leung, P.S. (2009), "The normalised revealed comparative advantage index", The Annals of Regional Science, Vol. 43 No. 1, pp. 267-282. 


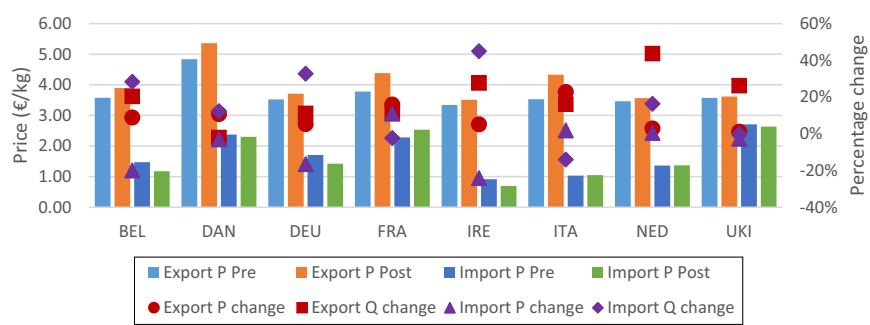

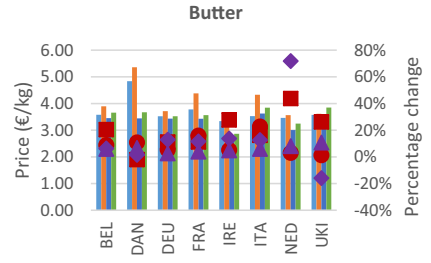

Skimmed dried milk

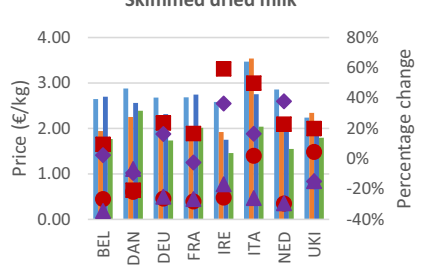

Skimmed cow milk

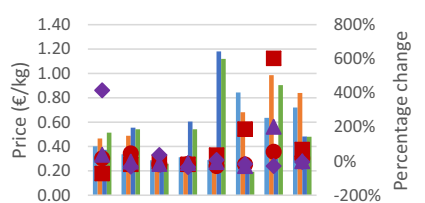

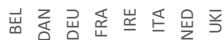
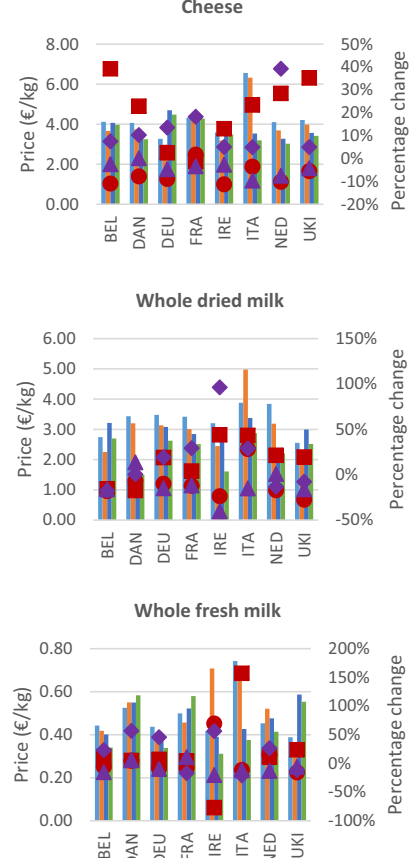

Whey

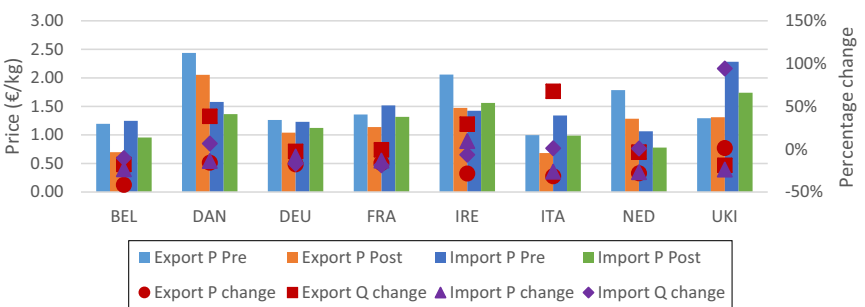

Source: Authors' calculations based on FAOstat dataset
Figure A1.

Dairy products export and import price and quantity growth rate pre and post-quota 
$\mathrm{CR}$

32,7

20

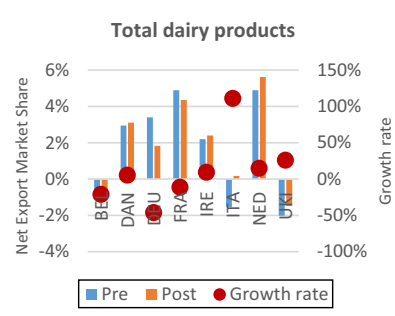

Cheese

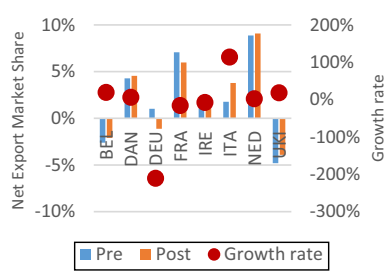

Skimmed dried milk

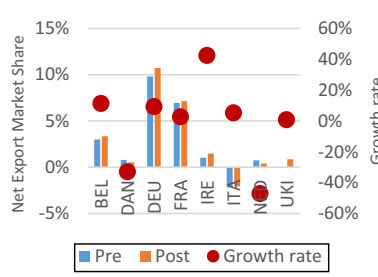

Whole fresh milk

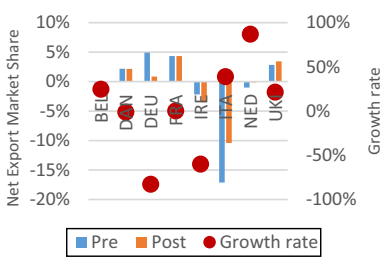

Butter

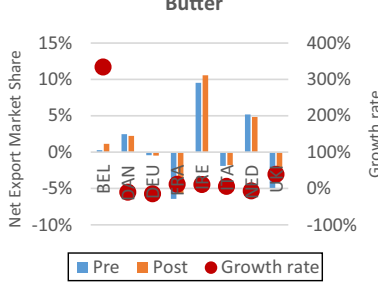

Skimmed cow milk

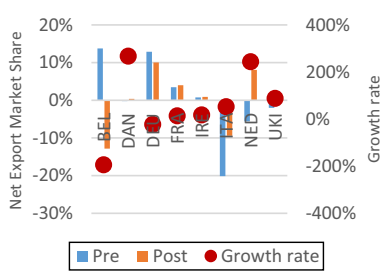

Whole dried milk

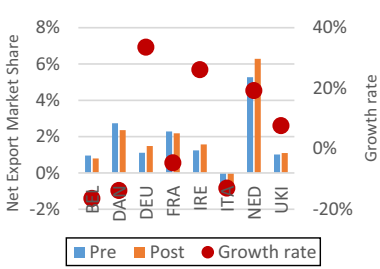

Whey

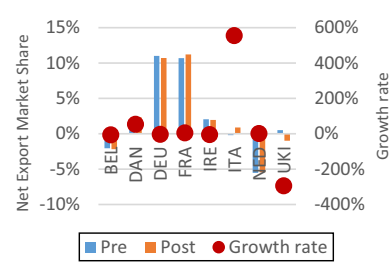

GPre $\quad$ Post Growth rate

Source: Authors' calculations based on FAOstat dataset

Figure A2.

Dairy net export market share $(\%)$ in the world pre and post-quota
Corresponding author

Lungelo Prince Cele can be contacted at: lungelo.cele@gmail.com

For instructions on how to order reprints of this article, please visit our website: www.emeraldgrouppublishing.com/licensing/reprints.htm

Or contact us for further details: permissions@emeraldinsight.com 